\title{
Meter in Traditional Kakataibo Chants
}

\section{Alejandro Augusto Prieto Mendoza*}

\begin{abstract}
This paper studies the principal aspects of meter of three traditional Kakataibo chants (a Panoan group of Peruvian Amazonia). Regarding meter, Kakataibo chants exhibit patterns relevant for the cross-linguistic study of line and meter typology. I describe the Kakataibo system of versification as a quantitative meter that counts an exact number of moras and regulates the distribution of these by imposing grouping restrictions; also, it establishes weight differences between light, heavy and superheavy syllables, and vowel lengthening plays an important role for meter purposes. In addition, the average duration of lines tends to last less than three seconds and decreases progressively during performance.
\end{abstract}

Keywords: Amazonia, verbal art, meter, versification

\section{Introduction}

Amazonia is still one of the least studied linguistic areas of the planet. In relation to this, chants in the Amazon, although their scientific documentation and analysis can be dated from the mid-twentieth century onwards, still can provide us with enough discoveries to challenge our current theories. In addition to forming a linguistic area (Epps, Michael 2017), the Amazon basin is also a discursive area (Beier, Michael, Sherzer 2002), on the one hand, due to the widespread presence of discourse forms and processes between different linguistic families and, on the other hand, because these forms and processes coexist in particular discursive genres (2002: 125). Some of these discourse forms are parallelism (Sherzer 1983), repetition (Beier et al. 2002; Journet 2000), shamanic discourse (Baer 1994; Brabec de Mori 2011, 2012; Seeger 1987), ceremonial dialogues (Urban 1986), etc., and might show unique features.

According to Edmonson (1971; cited in Tedlock 1983), there is no meter based on recurrent quantifications of vowel length, stresses, number of syllables, or of any other type, in indigenous Amerindian verbal art. However,

* Author's address: Alejandro Augusto Prieto Mendoza, Pontificia Universidad Católica del Perú; Universidad Tecnológica del Perú; Av. Universitaria Nº 1801, San Miguel, Lima, Perú; e-mail: alejandro.prieto.mendoza@gmail.com. 
recent studies prove otherwise (Beier 2001; Beier et al. 2002; Michael 2004; Skilton 2017). Thus, this paper contributes to the debate by presenting a study of the meter of three traditional Kakataibo chants. Regarding meter, I propose that these three Kakataibo chants exhibit a quantitative meter that counts an exact number of eight moras and regulates the distribution of these by imposing grouping restrictions; also, it establishes weight differences between light, heavy and superheavy syllables following the Khalkha criterion (Ryan 2019) .

This paper is organized as follows: in $₫ 1$, I offer a brief profile of the Kakataibo language and its speakers with a special emphasis on its syllable structure, stress and monosyllables. In $\$ 2$, I detail the two databases used in this paper and the number of lines and the total amount of syllables analyzed. In $\$ 3$, I recap some cultural topics about Kakataibo chants. In $\$ 4$, I discuss Michael's (2019) classification of edge-marking lines and meter-based lines and the meter typology following Aroui (2009) and Ryan (2017, 2019). In $\$ 5$, I analyze Kakataibo meter by discussing three chants: ño xakwati 'the hunt of the peccary', no bana 'iti 'the word of the enemy' and bana tuputi 'words of teaching. Finally, I conclude this paper in $\$ 6$ giving some reflections about the Kakataibo system of versification and the importance of this research area for the understanding of Amazonian verbal art and the cross-linguistic study of meter.

\section{Some notes on the Kakataibo language and its speakers}

Kakataibo is a Peruvian Amazonian language of the Panoan family and its speakers live in Huánuco and Ucayali. According to the last census of Instituto Nacional de Estadística e Informática (2017), 1553 people identified themselves as Kakataibo speakers. Regarding the Kakataibo dialectology, Zariquiey (2011b, 2013) identifies a primary division into two branches, one composed of the Lower Aguaytía, Upper Aguaytía, and Sungaroyacu dialects, and another one of the San Alejandro and Nokamán dialects. The chants analyzed in this article come entirely from the Lower Aguaytía variety and were recorded in two native communities: Mariscal Cáceres and Yamino. As for the Kakataibo phonology, the Lower Aguaytía dialect has the phonological inventory in Table 1 and 2 (orthographic conventions are included in brackets). 
Table 1. Inventory of the Kakataibo consonants

\begin{tabular}{|l|l|l|l|l|l|l|}
\hline \multirow{2}{*}{$\begin{array}{l}\text { Place of } \\
\text { articulation }\end{array}$} & Labial & $\begin{array}{l}\text { Dento- } \\
\text { alveolar }\end{array}$ & $\begin{array}{l}\text { Palato- } \\
\text { alveolar }\end{array}$ & $\begin{array}{l}\text { Palatal } \\
\text { (retro- } \\
\text { flex })\end{array}$ & Velar & Glottal \\
\hline Nasal & $\mathrm{p}<\mathrm{p}>$ & $\mathrm{t}<\mathrm{t}>$ & & & $\mathrm{k}<\mathrm{k}>$ & $\mathrm{P}<^{\prime}>$ \\
\hline & $\mathrm{m}<\mathrm{m}>$ & $\mathrm{n}<\mathrm{n}>$ & $\mathrm{n}<\tilde{\mathrm{n}}>$ & & $\mathrm{k}^{\mathrm{w}}<\mathrm{kw}>$ & \\
\hline Flap & & $\mathrm{f}<\mathrm{r}>$ & & & & \\
\hline Affricate & & $\widehat{\mathrm{ts}}<\mathrm{ts}>$ & $\widehat{\mathrm{t} \int}<\mathrm{ch}>$ & & & \\
\hline Fricative & & $\mathrm{s}<\mathrm{s}>$ & $\int<\mathrm{sh}>$ & $\mathrm{S}<\mathrm{x}>$ & & \\
\hline Approximant & $\beta_{\mathrm{r}}<\mathrm{b}>$ & & & & & \\
\hline
\end{tabular}

Table 2. Inventory of the Kakataibo vowels

\begin{tabular}{|l|l|l|l|l|l|}
\hline & Front & & Central & & Back \\
\hline High & $\mathrm{i}<\mathrm{i}>$ & & $\mathrm{i}<\ddot{\mathrm{e}}>$ & & $\mathrm{u}<\mathrm{u}>$ \\
\hline Mid & & $\mathrm{e}<\mathrm{e}>$ & & $\gamma<\mathrm{o}>$ & \\
\hline Low & & & $\mathrm{a}<\mathrm{a}>$ & & \\
\hline
\end{tabular}

Syllables in Kakataibo may be of the shape $(\mathrm{C}) \mathrm{V}(\mathrm{C})$, resulting in four possibilities: V, CV, VC and CVC. All these syllables can appear in any position and the coda position may be filled by one of $/ \mathrm{n} /, / \mathrm{s} /, / \mathrm{s} / / \mathrm{s} /$ and, in some restricted cases, / / (Zariquiey 2011a, 2018). It is important to highlight that vowel length is not contrastive in Kakataibo; however, as we will see later, vowel lengthening plays a special role in the Kakataibo meter. Regarding its metrical stress system, trochaic feet are created from left to right if there are no closed syllables in even positions and the acoustic correlate of stress is a pitch peak. However, if the second syllable is closed, it becomes the head of its foot and attracts the stress. In this sense, the Kakataibo metrical stress system is sensitive to syllable weight and closed syllables are treated as heavy (Zariquiey 2018: 119).

Regarding the behavior of the monosyllables in the language, Zariquiey (2011a: 150, 2018: 127-128) proposes that every phonological word in Kakataibo follows the principle of minimum phonological word; that is, a phonological word in Kakataibo is a prosodic unit that consists of at least two syllables (one foot) and one stress. Thus, for example, the monosyllables in (4) must be analyzed as phonologically disyllabic for stress assignment 
purposes - this principle also applies to monosyllabic roots. Monosyllables and monosyllabic roots have a complicated behavior in Kakataibo meter.

$\begin{array}{lll}\text { (1) } & & \\ \text { bi 'mosquito' } & >[\beta \hat{i ̣ ̂}] & \text { ('bí.i) } \\ \text { ba 'egg, larva' } & >[\beta \hat{a} \text { : }] & \text { ('bá.a) } \\ \text { bu 'hair' } & >[\beta \hat{̣}:] & \text { ('bú.u) }\end{array}$

(Zariquiey 2011a: 150)

As for the morphosyntactic profile, Kakataibo is a postpositional and agglutinating language showing high levels of synthetic verbal morphology. Word order is pragmatically-oriented, however verb-final sentences are the norm (Zariquiey 2018). In addition, Kakataibo has a rich switch-reference system and uses nominalizations systematically in discourse (also in chants).

\section{Data and Methodology}

The corpus used in the present article comprises a total of 10 chants (4 no bana 'iti, 3 bana tuputi and 3 no xakwati) - shown in Table 3. These 10 chants come from two databases: Zariquiey (2014) and my own fieldwork during 2015-2017. From Zariquiey (2014), I used seven songs documented in Yamino during the years 2010-2012; these songs were recorded using a ZOOM-H4 recorder, in uncompressed format WAV (stereo, digitized at a ratio of 44,100 $\mathrm{Hz}$ and 16 bits). In addition, I add three more chants of my own fieldwork in Yamino and Mariscal Cáceres; these were recorded with a Sony ICD-PX312.

In total, I have analyzed four no bana 'iti (4 different singers in different years and from two different communities), three bana tuputi (2 different singers, same year and community) and one ño xakwati (one singer in different years). I used PRAAT for acoustic analysis (Boersma and Weenik 2014) and Excel for statistics. In total, my corpus has 672 lines (Table 3) and I measured the actual duration of 2410 syllables (Table 4$)^{2}$.

2 As I expose in 5.2, Figure 6, Table 6, heavy and superheavy syllables differ each other only by duration in traditional Kakataibo chants. Superheavy syllables only appear in chanting due to metric requirements. 
Table 3. Metadata and number of lines per chant

\begin{tabular}{|l|r|}
\hline Chants and metadata & Number of lines \\
\hline ZQ-EE-nobana1-2010 & 67 \\
\hline ZQ-EE-nobana2-2010 & 120 \\
\hline AP-RA-nobana1-2017 & 54 \\
\hline AP-MA-nobana1-2017 & 40 \\
\hline ZQ-IO-banatuputi1-2010 & 81 \\
\hline ZQ-IO-banatupu2-2010 & 142 \\
\hline ZQ-CV-banatuputi1-2010 & 57 \\
\hline AP-EE-ñoxakwati1-2015 & 27 \\
\hline ZQ-EE-ñoxakwati1-2010 & 36 \\
\hline ZQ-EE-ñoxakwati2-2010 & 48 \\
\hline Total & 672 \\
\hline
\end{tabular}

Table 4. Type and number of syllables measured

\begin{tabular}{|l|r|}
\hline Type of syllable & $\#$ \\
\hline Light & 1944 \\
\hline Heavy & 146 \\
\hline Superheavy & 320 \\
\hline Total & 2410 \\
\hline
\end{tabular}

\section{A brief summary of kakataibo chants}

In previous works (Prieto Mendoza 2018, 2019), I have studied different topics of the Kakataibo traditional chants such as the learning process of the singers, the available recording and databases, the number of types of chants, etc. so in this paper I only discuss some aspects related to ño xakwati, no bana 'iti, and bana tuputi.

The traditional Kakataibo chants, in general, are always improvised in each performance, which puts them in the line with areal tendencies of Amazonian ritual chant (Déléage 2020). As stated by Erwin Frank, the kakataibos never "sing a song in the same way as on other performance [...] However, singers 
believe that their different versions of a song are 'always absolutely the same'" (Frank 1994: 227). Thus, although the content is always improvised and varies in each performance, every Kakataibo learns a discursive technique of formalization that remains stable across singers. In relation to the linguistic aspects of this discursive technique, the Kakataibo traditional chants exhibit a high metaphorical content, reduced syntax, specialized vocabulary, and three compositional strategies (Frog 2009): semantic parallelism, enjambment, and repetition (Prieto Mendoza 2019). In addition, as I propose in this paper, three Kakataibo traditional chants exhibit a metrical organization: ño xakwati, no bana 'iti, and bana tuputi.

No xakwati is sung before hunting or during the last hours of the night to attract the ño 'peccary'. Kakataibos, as other Panoan groups, raise peccaries and when these peccaries are sufficiently grown to eat, families or neighboring groups gathered to kill the raised peccary. During this festivity, no longer practiced, men also sing ño xakwati.

Bana tuputi is a women's chant about life experiences with special attention to the parents or related family that raised her in her childhood. By singing bana tuputi, the singer instructs her offspring in the Kakataibo way of life.

Lastly, no bana 'iti is also about life experiences that marked the life of the male singer, such as military service, some physical prowess or how he learned to hunt. Kakataibo tend to highlight their physical abilities and the aptitude of not being deceived using the figure of the 'inu 'jaguar'. The mythological figure of the 'inka plays an important role in the imagery of no bana 'iti and is associated with metal tools, airplanes, boats or products considered brought by the mestizos 'non Kakataibos, foreigners'.

In terms of the continuity of this practice, many Kakataibos declare that they no longer know how to sing "traditional chants"; however, a considerable group of adults, between 50 - and 80 -year-olds, actively sing and seek to revitalize this practice. It is also worth noting that nowadays the vitality of this practice can be considered endangered since many of the singers are only elders or have died in the last two years.

\section{Line and meter typology}

One of the most important theoretical contributions of the ethnopoetic studies was to propose that Amerindian verbal art is organized around structuring textual or discursive units called lines (Hymes 1981). Lines are defined by patterns and recurrence of different types, for example, the recurrence of certain 
discursive particles at the beginning of the line, prosodic or intonation features, final vowel lengthening, phonological phrasing, parallelism, repetition, etc. (Severi 2008; Sherzer 1983; Sherzer, Wicks 1982; Urban 1988). According to Michael (2019), these recurrences are not seen "as not merely aligning with the edges of a pre-existing constituent (i.e the line), but rather as themselves constituting the line edges, and thereby creating the line" (2019: 57). Likewise, lines can be classified in two types: edge-marking lines and metrical lines. The former is defined by discursive particles, prosodic features or syntactic phrasing but meter is not used, while the latter use recurrence patterns of phonological segments such as syllables, stress, moras or tone. Traditionally, metrical lines have been the prototypical object of study for metrics and versification. Regarding the areal diffusion of these two type of lines among Amerindian languages, Edmonson (1971) considers that Amerindian verbal art lacks any type of metrical lines and, on the contrary, edge-marking lines would be predominant. However, recent studies prove otherwise, for example the verbal art of the Curripaco (Journet 2000), Wampis (Peña 2018), Nanti (Beier 2001; Michael 2004) and Máihł̃ki (Skilton 2017) were found to exhibit metrical lines, so there is now ample counterevidence against Edmonson's (1971) claim.

On another note, regarding metrical lines, different typologies have been proposed (Aroui 2009; Dufter 2010; Fabb 1997; Fabb, Halle 2008; Lotz 1960; Tsur 1998). According to Aroui (2009), we need two criteria in order to distinguish and compare metrical lines between the world's languages: prosodic constituents and type of organization. The first criterion refers to the type of prosodic unit on which the verse is based (mora, stress, syllable or tone); the second takes into consideration the type of organization of these units, whether it is counting or patterning. Examples of moraic-counting meters are Japanese classic poetry; syllable-counting meters, Spanish or French; on the other hand, patterning meters are used in Hausa, classic Arabic, Latin and ancient Greek, etc.

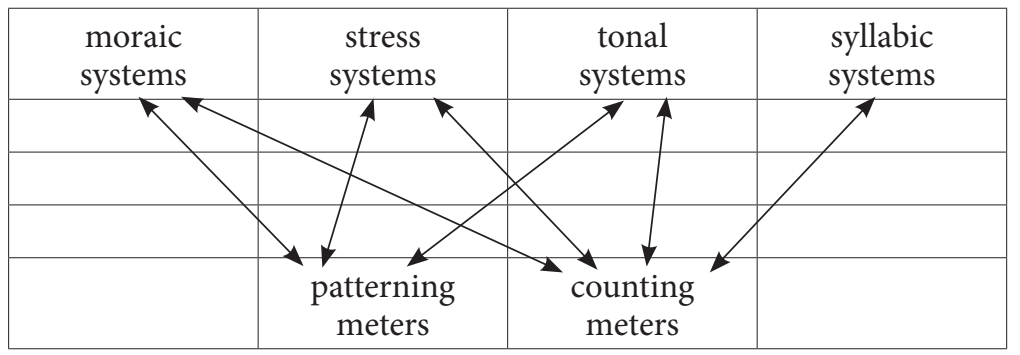

(Aroui 2009: 15)

Figure 1. Verse typology 
Following Ryan (Ryan 2017, 2019), another important classification is the distinction between quantitative and accentual meters - because Kakataibo chants use a quantitative meter, I only discuss the first one. A meter is quantitative if it is based on syllable weight or mora count - moraic systems and syllabic systems following Aroui (2009). According to Ryan (2019), quantitative meters vary in terms of the importance they give to syllables or moras, this is schematized in the following continuum.

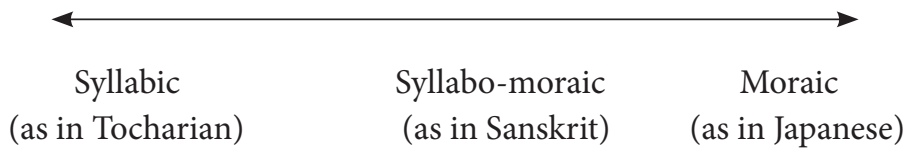

Ryan (2019: 134)

Figure 2. Typological range of quantity sensitivity in meter

On the left extreme of this continuum, syllabic-counting meters fix the number of syllables per line regardless of their weights, languages lacking phonemic vowel length tend to use this meter. At the right extreme, mora-counting meters fix a number of moras per line but, in some extreme cases, the syllable structure is ignored. According to Ryan, "within this range, meters vary widely in how sensitive they are to moras vs. syllables" (2019: 136).

On the other hand, quantitative meters can be classified based on of these two weight criteria: the Latin criterion or the Khalkha criterion. The first one considers that a syllable is light if and only if it has the structure $\mathrm{C}_{0} \mathrm{~V}$; syllables with codas count the same as long vowels. The majority of the quantitative meters studied by Ryan (2019) follow the Latin Criterion - they come from the most widespread poetic traditions, Indo-European and Semitic. The second one establishes that a syllable is light if and only if it has the structure $\mathrm{C}_{0} \mathrm{VC}_{0}$, in other words, if it contains a short vowel regardless the presence of a coda the Khalkha criterion is considerably less common. For example, karintaa chants of the Nantis, an Arawakan group of the Peruvian Amazon, follow the Khalkha criterion. In karintaa, long vowels count as bimoraic for meter purposes, but nasal codas (the only codas allowed by Nanti phonotactics) are ignored (Michael 2004). As proposed in $\$ 5.1$, Kakataibo meter follows the Khalkha criterion, whereby long vowels count as two moras, while codas fail to contribute a mora. Furthermore, even though weight distinctions are usually binary, some traditions distinguish heavy vs superheavy syllables (i.e trimoraic) - superheavy syllables are also important in the Kakataibo meter. Also, there are two putative universals of quantitative meter: final indifference and 
final strictness. First, it is common for the weight to be ignored in the line-final position, because this position tends to be lengthened or due to extrametricality, final syllables are in fermata. Second, endings, not only line-final endings but across metrical constituents, are stricter than beginnings (Ryan 2019: 136).

Finally, it should be added that there also exist hybrid accentual-quantitative meters. Following Ryan (2017), such hybrid meter can be classified in two classes: (i) weight and stress map independently on the meter, and (ii) weight and stress interact, with the weight being more regulated than the latter.

At last, another important topic related to line typology is the line duration. Fabb (2015) proposes that there is no fixed limit for the duration of lines, and the crucial constraint in line duration is the amount and organization of information; on the contrary, Turner and Pöppel (1988) propose that lines tend to last between $2.5 \mathrm{~s}$ and $3.5 \mathrm{~s}$.

\section{Kakataibo system of versification}

As shown in the Introduction, this article discusses the metrical structure of three Kakataibo chants, no xakwati, bana tuputi and no bana 'iti. In the following sections, I discuss the principal aspects of the Kakataibo system of versification according to its relevance for each chant: syllabic behavior (Khalkha criterion), vowel lengthening and line duration are discussed on the material of no xakwati, and superheavy syllables and mora suppression are exemplified with no bana 'iti and bana tuputi.

\subsection{No xakwati and basic aspects}

The first thing to comment on the following examples in (2) is that, the lines in (a-e) each have 8 moras - defined as "the temporal duration of the syllable that contains a short vowel" (Banti, Giannattasio 1996), even though the number of syllables may vary across lines.

(2)

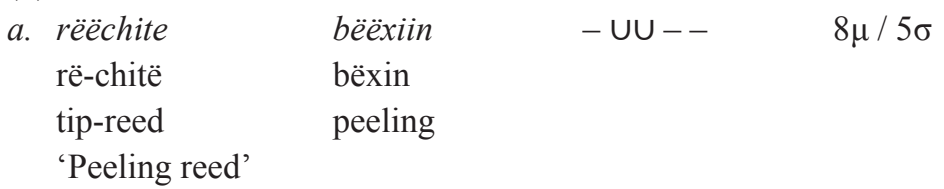



b. shinkun runu pibëtsiin $\quad \cup \cup \cup \cup \cup-\quad 8 \mu / 7 \sigma$
shinkun runu pi-bëtsin
snake eat-coming
'The snake is coming'
c. basi runu pibëtsiin $\cup \cup \cup \cup \cup \cup-8 \mu / 7 \sigma$
basi runu pi-bëtsin
snake eat-coming
'The snake is coming'
d. tashiaa rëchinkiin UU - UU - $8 \mu / 6 \sigma$
tashia rëchin-kin
river sniff-S/A $>$ A(SE)
'Sniffing around the Tashia river'
e. 'inu ñoo rëkwënaan $\cup \cup \cup U^{*} \cup U-8 \mu / 7 \sigma$
inu ño rëkwë-anan
tiger peccary go.forward-S/A $>\mathrm{S} / \mathrm{A}(\mathrm{SE})$
'The peccary is going forward'

Thus, I postulate the following metric pattern for ño xakwati:

(3)

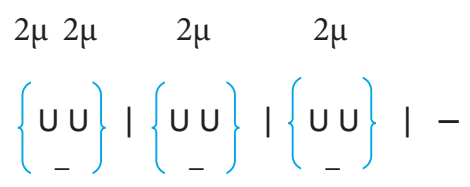

This formalization suggests that the first three metrical feet can be composed of either two short vowels or a lengthened vowel, as evidenced by (a) and (e), while the last foot necessarily has to be performed with a syllable carrying a lengthened vowel. Furthermore, for the Kakataibo versification system in general, a closed syllable with a short vowel does not count metrically as a syllable with a lengthened vowel, but as an open syllable with a short one. Thus, Kakataibo versification follows the Khalkha criterion. For example, as we see in (b-c), the first foot of (b) is composed of two closed syllables, <shin $>$ and $<$ kun $>$, and the first foot of (c) with two open syllables, $<$ ba $><$ si $>$; however, comparing these with the first syllable with a lengthened vowel in (a), we see that the Kakataibo versification system establishes a weight distinction between light and heavy syllables, and a syllable is heavy if it has a lengthened 
vowel, also codas are ignored. It is important taking into consideration that the prosody system of the language is also sensitive to weight as I describe in $\$ 1$; fact that suggests that the weight criteria differs in everyday speech and singing.

In addition, in (e), we see that the monosyllable $<$ ño $>$, which has a "lengthened" vowel in surface, has been represented in the same way as two short vowels $\left.{ }^{*}\right)$. This decision has been taken considering that monosyllables and monosyllabic roots must be analyzed as phonologically bisyllabic, and to differentiate monosyllables from strictly lengthened vowels due to versification.

On the other hand, bars, or metrical foot boundaries, tend to coincide with word boundaries, this indicates that usually two syllables of different words are not grouped in the same foot. Nevertheless, in all the corpus, there only a few cases in which two syllables of different words have been grouped in the same foot, or cases in which the singer does not follow the metrical bars; I interpret these cases as stylistic deviations for aesthetic purposes. Finally, consider the following Figure 3, which shows the duration of light and heavy syllables in seconds.

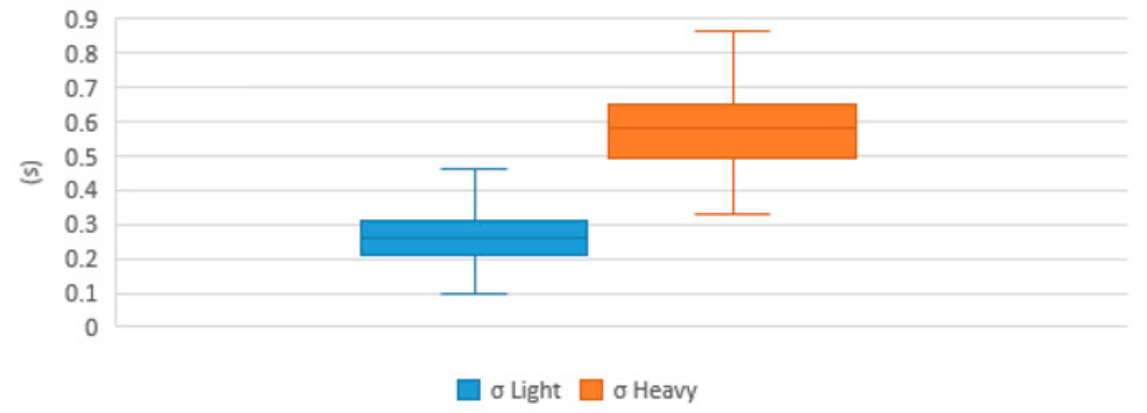

Figure 3. Type of syllable and duration

As we can see, light syllables tend to last on average (0.21s) and heavy syllables $(0.49 \mathrm{~s})$; thereby, I propose that a light syllable, that is a syllable with a short vowel, carries $1 \mu$ and a heavy syllable or a syllable with a lengthened vowel carries $2 \mu$, in accordance with the Khalkha criterion. Superheavy syllables are not included in Figure 3 because they are not employed in ño xakwati - see 5.2. 
Table 5. Type of syllable and metrical representation

\begin{tabular}{|c|c|c|}
\hline \multicolumn{3}{|c|}{ Syllable weight in Kakataibo chants } \\
\hline Type of syllable & Metrical representation & Moras \\
\hline$(\mathrm{C}) \mathrm{V}(\mathrm{C})$ & $\mathrm{U}$ & $1 \mu$ \\
\hline$(\mathrm{C}) \mathrm{V}:(\mathrm{C})$ & - & $2 \mu$ \\
\hline
\end{tabular}

\subsubsection{Vowel lengthening}

As for vowel lengthening, we must first specify that, phonetically, monosyllables and heavy syllables $(\mathrm{C}) \mathrm{V}:(\mathrm{C})$ have the same duration values; however, as discussed in $\$ 1$, monosyllables are obliged to a priori follow the minimum phonological word principle, so I opted to consider them metrically as two light syllables. Because of this, monosyllables and the lines in which they appear have been excluded from the analysis to distinguish them from heavy syllables. On the other hand, in case the number of moras in the line does not satisfy $8 \mu$, kakataibo singers create artificially lengthened vowels taking into account that (i) the metric template should be respected, (ii) there are predetermined lengthenings positions according to the particular metric organization of a chant, (iii) grouping two syllables of different words in the same foot is avoided, and (iv) there is a tendency to lengthened vowels following the stress pattern of the language. To exemplify this, see the case in (4).

(4)

shuinkikiraatsuu

shuinki $\mathrm{ki}_{2}=$ ratsu

oncilla $=$ DIM

'Little tiger cat (Leopardus tigrinus)'

* shuinkiiki ratsuu

shuinkiki raatsuu

$\cup \cup|-| \cup \cup \mid-$
$\cup \cup|\cup \cup|-\mid-$

In (4) we have two phonological words, shuinkiki 'oncilla' and =ratsu 'DIM'. First, the final syllable $<$ tsu $>$ is lengthened due to the ño xakwati's meter; then, the number of remaining moras is 5 , so a vowel should be lengthened. Following the stress patterns in Kakataibo, syllables $<$ kil $>$ and $<$ ra $>$ can be lengthened. However, if $<$ kil $>$ is lengthened, syllables $<$ ki2 $>$ and $<$ ra $>$ would be in the same foot violating the principle of not grouping two syllables of different words in the same foot. On the contrary, $<\mathrm{ra}>$ is lengthened satisfying (3). See the next example in (5). 
(5)

$$
\begin{array}{ll}
\text { rëëchinkin rëchinkiin } & \\
\text { rë }_{1} \text { chin }_{1}-\text { kin }_{1} \text { rë }_{2} \text { chin }_{2}-\mathrm{kin}_{2} & \\
\text { sniff-S/A }>\mathrm{A}(\mathrm{SE}) \quad \text { sniff-S/A }>\mathrm{A}(\mathrm{SE}) \\
\text { 'Sniffing, sniffing' } \\
\text { * rëchiinkin rëchinkiin } & \cup-\cup|\cup \cup|- \\
\text { * rëchinkin rëchiinkiin } & \cup \cup|\cup \cup|-\mid- \\
\text { * rëchinkin rëëchinkiin } & \cup \cup|\cup-|- \\
\text { rëëchinkin rëchinkin } & -|\cup \cup| \cup \cup \mid-
\end{array}
$$

First, the last syllable in (5), $\left\langle\mathrm{kin}_{2}>\right.$, is lengthened due to the metric organization of ño xakwati. Then, the number of remaining moras is 5 , so the line does not have the total amount of moras, 8 , and one more mora is missing. Thus, following the stress pattern of Kakataibo, both $<\operatorname{chin} 1>$ and $<$ chin $2>$ can be lengthened; however, it is not possible to lengthened any of them because if $<$ chin $1>$ is lengthened the order proposed in (3) would not be followed and if $<$ chin $2>$ is lengthened two syllables of different words, $<$ kin $1>$ and $<$ rë $2>$, would be grouped in the same foot; in addition, $<$ rë $2>$ has the same problem of $<$ chin $1>$. Thus, $<$ rë1 $>$ is lengthened satisfying (3) despite not being the nucleus of its foot. Now, see the next example in (6).

(6)

$\begin{array}{ll}\text { tashiaa } & \text { rëchinkiin } \\ \text { tashia } & \text { rëchin-kin }\end{array}$

river sniff-S/A $>\mathrm{A}(\mathrm{SE})$

'Sniffing around the Tashia river'

$$
\begin{aligned}
& * \cup \cup|\cup \cup|-\mid- \\
& -|\cup \cup| \cup \cup \mid- \\
& \cup \cup|-| \cup \cup \mid-
\end{aligned}
$$

As in (5), in (6) <kin > is lengthened due to a predetermined metric organization and $<$ chin $>$ cannot be lengthened because $<$ a $>$ and $<$ rë $>$ would be in the same group. However, (6) does not follow the stress pattern of Kakataibo, because $<$ ta $>$ is not the lengthened syllable, but $<a>$. In addition, we have to consider that each of these two possible realizations both follow all of the principles proposed until here. In interpret this case as a manifestation of the creativity and stylistic play that kakataibo singers do for aesthetic purposes. Finally, vowel lengthening is done as many times as necessary to fulfill the meter template. 
(7)

$\begin{array}{ll}\text { rëëchitë } & \text { bëëxin } \\ \text { rë-chitë } & \text { bëxin } \\ \text { tip-reed } & \text { peeling } \\ \text { 'Peeling reed' } & \\ -|\cup \cup|-\mid- & \end{array}$

As shown, considering that the last syllable must be heavy, there are not enough syllables for the remaining six moras, since there are only four light syllables. Therefore, both syllables $<$ rë $>$ and $<$ bë $>$ are lengthened following the prosodic system of the language and fulfilling the first and the third foot respectively. At last, we see in Table 6 that vowel lengthening is a relatively productive strategy in Kakataibo chants, although the tendency is to perform the meter without lengthenings. Also, lengthening is more common in the first foot than in the second and third. Lines with monosyllables have been excluded in Table 6. In addition, examples like (7) with two lengthenings are extremely rare and one lengthening is the common strategy. In fact, (7) is the only case documented in all my data with two lengthenings; due to this I put (7) in 'Other'.

Table 6. Type of scansion per chant

\begin{tabular}{|c|r|r|r|r|r|r|r|r|}
\hline Lines & \multicolumn{2}{|c|}{$\begin{array}{c}\text { EE-ñoxak- } \\
\text { wati1-2010 }\end{array}$} & \multicolumn{2}{c|}{$\begin{array}{c}\text { EE-ñoxak- } \\
\text { wati2-2010 }\end{array}$} & \multicolumn{2}{c|}{$\begin{array}{c}\text { EE-ñoxak- } \\
\text { wati-2015 }\end{array}$} & \multicolumn{2}{c|}{ Total } \\
\hline$\cup \cup|\cup \cup| \cup \cup \mid-$ & 15 & $60.00 \%$ & 20 & $71.43 \%$ & 10 & $66.67 \%$ & 45 & $66.18 \%$ \\
\hline$-|\cup \cup| \cup \cup \mid-$ & 5 & $20.00 \%$ & 7 & $25.00 \%$ & 3 & $20.00 \%$ & 15 & $22.06 \%$ \\
\hline$\cup \cup|-| \cup \cup \mid-$ & 4 & $16.00 \%$ & 0 & $0.00 \%$ & 0 & $0.00 \%$ & 4 & $5.88 \%$ \\
\hline$\cup \cup|\cup \cup|-\mid-$ & 1 & $4.00 \%$ & 0 & $0.00 \%$ & 2 & $13.33 \%$ & 3 & $4.41 \%$ \\
\hline Other & 0 & $0 \%$ & 1 & $3.57 \%$ & 0 & $0.00 \%$ & 1 & $1.47 \%$ \\
\hline
\end{tabular}

\subsubsection{Duration of lines}

In the three ño xakwati chants analyzed, lines usually last on average less than three seconds (Figure 4). This average duration applies to ño xakwati, no bana 'iti and bana tuputi. This fact supports the hypothesis of Turner and Pöppel (1988). However, it is necessary to take into account the debate regarding the duration of the lines and their implications for information processing (Fabb 2015). 


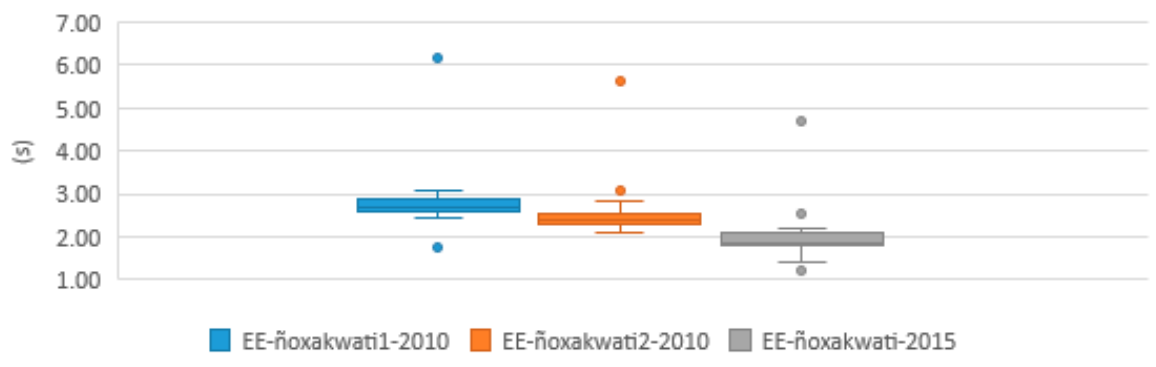

Figure 4. Average of line duration in three ño xakwati

Also, the duration of lines usually decreases progressively, or, in other words, singers tend to increase their tempo. For example, in these three ño xakwati, the first line lasts $3.09 \mathrm{~s}, 3.08 \mathrm{~s}$ and $2.52 \mathrm{~s}$ seconds respectively. In addition, considering the total number of lines of each song, the middle line lasts $2.57 \mathrm{~s}$ (line 17), 2.45s (line 24), and 1.72s (line 13); and the penultimate line, 1.77s, 2.29s, and $1.22 \mathrm{~s}$. Thus, we see a decrease of approximately $17 \%$ between the first line and the middle line and, on the other hand, $43 \%$ between the first line and the penultimate line. Finally, the last line of no xakwati ends with an extreme lengthening in the final syllable so the final line lasts $6.19,5.62$, and $4.70 \mathrm{sec}-$ onds. This lengthening at the end of no xakwati should not be confused with the phenomena previously studied as it is merely a stylistic resource associated with this chant.

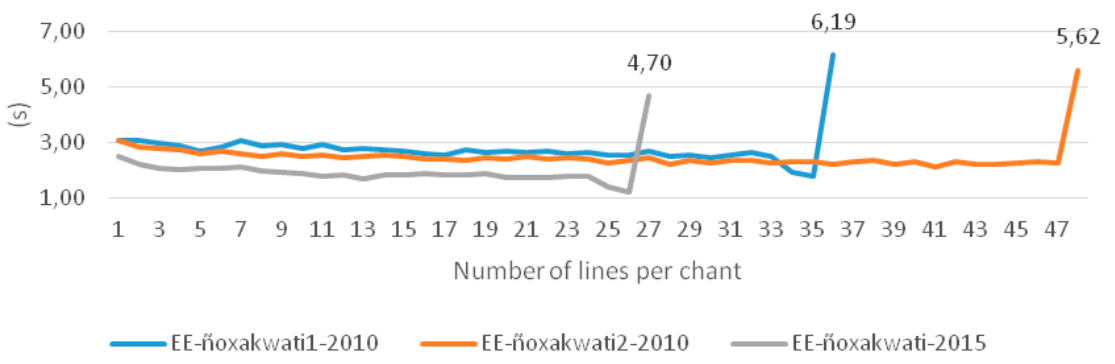

Figure 5. Line duration in three ño xakwati 


\subsection{No bana 'iti and bana tuputi}

As for no bana 'iti and bana tuputi, I proposed the same metric pattern for both chants $^{3}$ :

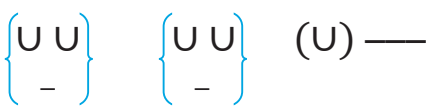

Like ño xakwati, the first two subparts are made up of two light syllables or one heavy syllable; however, unlike in ño xakwati, the last four moras can be realized in no bana 'iti and bana tuputi as $<\mathrm{U} \longrightarrow>, 4$ moras, or $<\longrightarrow, 3$ moras, the segment $(U)$ may be realized or not realized. The suppression of $(U)$ is most common in bana tuputi than in no bana 'iti. This indicates that Kakataibo traditional chants can have their own specific meter. In addition, following line typology, we could consider that final syllables are long to mark the limits and the completion of a line; however, as proposed in the next section on syllabic suppression, superheavy syllables (trimoraic vowels) are necessary for the analysis. Regarding the average duration of the superheavy syllables, we see in Figure 6 that they last (0.86s), differentiating them from light syllables (0.21s) and heavy syllables (0.49s).

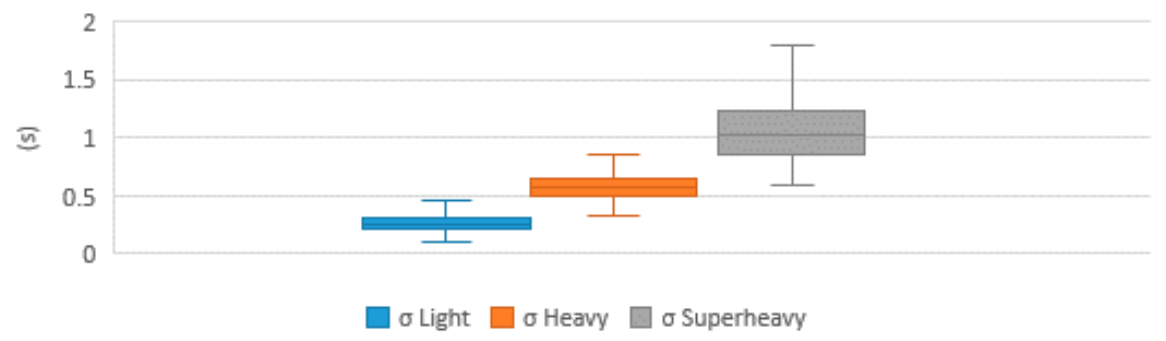

Figure 6. Type of syllable and average duration

In this way, Table 5 is reformulated and I propose that Kakataibo system of versification distinguishes between light, heavy and superheavy syllables with Khalkha criterion as weight behavior.

\footnotetext{
3 Although the meter is the same, these two chants differ substantially in other aspects. For example, no bana 'iti is sung only by men, while bana tuputi only by women. For further clarification, see (Prieto 2015, 2019).
} 
Table 7. Metrical representation of light, heavy and superheavy syllables

\begin{tabular}{|l|l|l|}
\hline \multicolumn{3}{|c|}{ Syllable weight in Kakataibo chants } \\
\hline Type of syllable & Metrical representation & Moras \\
\hline$(\mathrm{C}) \mathrm{V}(\mathrm{C})$ & $\mathrm{U}$ & $1 \mu$ \\
\hline$(\mathrm{C}) \mathrm{V}:(\mathrm{C})$ & - & $2 \mu$ \\
\hline$(\mathrm{C}) \mathrm{V}::(\mathrm{C})$ & --- & $3 \mu$ \\
\hline
\end{tabular}

\subsubsection{Syllabic suppression and superheavy syllables}

On the other hand, regarding syllabic suppression, a phenomenon only documented in these two types of chants, see the following example of no bana 'iti (9).

(9)

$\begin{array}{lll}\cup \cup\left|\cup \cup^{*}\right|(U) & \\ \text { ain } & \text { xóon } & \text { 'iraaan } \\ \text { ain } & \text { xón } & \text { 'irapa-nën } \\ \text { 3sg.GEN } & \text { macaw } & \text { shotgun-INST }\end{array}$

'with his red shotgun (red as the macaw)'

The first thing to comment is that 'irapa-nën 'shotgun-INST' has been realized as <'iran>, because the meter in no bana 'iti allows two syllables in the last foot: one light, one superheavy, respectively. Thus, the segment, /rapanën/, which has three light syllables (or three moras), suffers the suppression of $<$ pa $>$ and $<$ në $(n)>$, relocating two moras to $<$ ran $>$, which, as it is postulated, is a superheavy syllable with three moras. This process is summarized in (10). In addition, I interpret xón as two light syllables due to kakataibo's principle of minimum phonological word as in 2(e), and to differentiate monosyllables from strictly lengthened vowels due to versification.
* ('i)rapanën
(U) UUU
'irapanën > 'ira(pa)(në)n
(U) --- 


\section{Summary}

The study of meter in the Amerindian verbal art, especially in Amazonia, is still an under-researched area in linguistics and other related fields. About meter, we do not know how common or uncommon it is among Amazonian verbal art and so far meter it has been documented in a few cases, despite Edmonson (1971). I consider that Amazonia can offer new questions and approaches for line and verse typology, as well as for musical and anthropological theory. In the following, I summarize my findings regarding the meter of three Kakataibo traditional chants: ño xakwati, no bana 'iti, and bana tuputi.

These three Kakataibo chants exhibit a quantitative verse that must have 8 moras and regulates the distribution of these by imposing grouping restrictions; also, for metrical purposes, the Kakataibo chants employ weight differences between light, heavy and superheavy syllables following the Khalkha criterion, this means that a syllable is heavy if it has a lengthened vowel, while the codas are ignored.

In addition, the singer follows four principles in order to fulfill the metric organization of each chant: i) the metric template should be respected, (ii) there are predetermined lengthenings positions according to the particular metric organization of a chant, (iii) grouping two syllables of different words in the same foot is avoided, and (iv) there is a tendency to lengthened vowels following the stress pattern of the language. Also, kakataibo singers manifest their creativity and expertise by creating unexpected lengthenings or breaking the metric template. Besides, lines tend to last less than three seconds. ${ }^{4}$

\footnotetext{
4 My thanks to all the kakataibos who collaborated in my fieldwork, specially to Emilio Estrella, elder and sabio of the Native Community of Yamino who has passed away in 2020. I would also like to express my thanks to the anonymous readers who reviewed this paper and to DGI-PUCP.
} 


\section{Abbreviations}

\begin{tabular}{|l|l|l|l|}
\hline$>$ & 'Interclausal co-referentiality' & SE & 'simultaneous dependent event' \\
\hline A & 'agent' & NOM & 'nominaliser' \\
\hline CAUS & 'causative' & non.prox & 'non-proximal to the addressee' \\
\hline DIM & 'diminutive' & NEG & 'negative' \\
\hline DS & 'different subjects' & PERF & 'perfective' \\
\hline IMPF & 'imperfective' & PLU & 'plural' \\
\hline INST & 'instrumental' & POE & 'posterior dependent event' \\
\hline
\end{tabular}

\section{References}

Aroui, Jean-Louis 2009. Introduction: Proposal for metrical typology. In: Aroui, JeanLouis; Arleo, Andy (eds.), Towards a Typology of Poetic Forms. Amsterdam: John Benjamins, 1-40.

Baer, Gehard 1994. Cosmología y shamanismo de los Matsiguenga (Perú oriental). Quito: Abya-Yala.

Banti, Giorgio; Giannattasio, Francesco 1996. Music and Metre in Somali Poetry. In: Hayward, Richard J.; Lewis, Ioan M. (eds.), Voice and power: Essays in honour of B. W. Andrzejewski (African Languages and Cultures. Supplement 3). London: School of Oriental and African Studies, 83-127. https://doi.org/10.2307/586655

Beier, Christine 2001. Creating comunnity: feasting among the Nantis of Peruvian Amazonia. Master's Thesis. The University of Texas at Austin.

Beier, Christine; Michael, Lev; Sherzer, Joel 2002. Discourse Forms and Processes in Indigenous Lowland South-America: An Areal-Typological Perspective. In: Annual Review of Anthropology 31, 121-145.

https://doi.org/10.1146/annurev.anthro.31.032902.105935

Brabec de Mori, Bernd 2011. Tracing Hallucinations: Contributing to a Critical Ethnohistory of Ayahuasca Usage in the Peruvian Amazon. In: Labate, Beatriz Caiuby; Jungaberle, Henrik (eds.), The Internationalization of Ayahuasca. Zurich: Lit Verlag, 23-47.

Brabec de Mori, Bernd 2012. About magical singing, sonic perspectives, ambient multinatures, and the conscious experience. In: Indiana 29, 73-101. 
Déléage, Pierre 2020. Toward an Epidemiology of Ritual Chants. In: Social Analysis 64(3), 113-144. https://doi.org/10.3167/sa.2020.640307

Dufter, Andreas 2010. Phonological theory and poetic practice: syllabic and accentual constraints in Romance versification. In: Phonological Typology of Syllable and Word Languages in Theory and Practice, a workshop held at FRIAS, Albert-LudwigsUniversitat Freiburg, 30 March 2010. https://www.frias.uni-freiburg.de/de/dasinstitut/archiv-frias/school-of-lili/veranstaltungen/Dateien_Veranstaltungen/du1

Edmonson, Munro S. 1971. Lore: An introduction to the science of folklore and literature. New York: Holt.

Epps, Patience; Michael, Lev 2017. The Areal Linguistics of Amazonia. In: Hickey, Raymond (ed.), The Cambridge Handbook of Areal Linguistics. Cambridge: University Press. https://doi.org/10.1017/9781107279872

Fabb, Nigel 1997. Linguistics and Literature: Language in the Verbal Arts of the World. Oxford: Blackwell.

Fabb, Nigel 2015. What is Poetry? Language and Memory in the Poems of the World. Cambridge: University Press.

Fabb, Nigel; Halle, Morris 2008. Meter in Poetry. A New Theory. Cambridge: University Press.

Frank, Erwin H. 1994. Los Uni. In: Granero, Fernando Santos; Barclay, Frederica (eds.), Guía etnográfica de la alta Amazonía. Quito: FLACSO, 129-237. https://doi.org/10.4000/books.ifea.2467

Frog 2009. Speech-acts in skaldic verse: Genre, compositional strategies and improvisation. In: Dewey, Tonya Kim; Frog (eds.), Versatility in Versification: Multidisciplinary Approaches to Metrics. New York: Peter Lang, 223-246.

Hymes, Dell 1981. "In Vain I Tried to Tell You". Essays in Native American Ethnopoetics. Philadelphia: University of Pennsylvania Press. https://doi.org/10.9783/9781512802917

Instituto Nacional de Estadística e Informática (INEI) 2017. Censo Nacional 2017.

Journet, Nicolas 2000. Dialogues chantés chez les Curripaco de rio Negro: un genre métaphorique. In: Monod Becquelin, Aurore; Erikson, Philippe (eds.), Les Rituels du Dialogue: Promenades Ethnolinguistiques en Terre Amerindiennes. Nanterre: Société d’ethnologie, 139-164.

Lotz, John 1960. Metric Typology. In: Sebeok, Thomas A. (ed.), Style in Language. MIT Press, 135-148. 
Michael, Lev 2004. Between Grammar and Poetry: The Structure of Nanti Karintaa Chants. In: Proceedings of the Eleventh Annual Symposium About Language and Society - Austin, April 11-13, 2003. (Texas Linguistic Forum 47), 251-262. http://salsa.ling.utexas.edu/proceedings/2003/michael.pdf

Michael, Lev 2019. Lines in Nanti Karintaa Chants: An Areal Poetic Typological Perspective. An essay in honor of Joel Sherzer. In: Cadernos de Etnolingüística 7(1), 56-62. http://www.etnolinguistica.org/article:vol7n1p56-64

Peña, Jaime 2018. The metrical structure of Jivaroan Nampet "drinking song." In: Amazonicas VII. Baños de Agua Santa, Ecuador.

Prieto Mendoza, Alejandro 2018. Estrategias de composición en el canto kakataibo. Una aproximación comparativa. Master's thesis. Lima: Pontificia Universidad Catolica del Peru.

Prieto Mendoza, Alejandro 2019. Semantic Parallelism in Traditional Kakataibo Chants. In: Open Linguistics 5(1), 383-404. https://doi.org/10.1515/opli-2019-0021

Ryan, Kevin M. 2017. The stress-weight interface in metre. In: Phonology 34(3), 581-613. https://doi.org/10.1017/S095267571700029X

Ryan, Kevin M. 2019. Prosodic Weight: Categories and Continua. (Oxford Studies in Phonology and Phonetics 3). Oxford: University Press.

Seeger, Anthony 1987. Why Suyá Sing: A Musical Anthropology of an Amazonian People. Cambridge: Cambridge University Press.

Severi, Carlos 2008. El Yo-memoria. Una nueva aproximación a los cantos chamánicos amerindios. In: Cuicuilco 15(42), 11-28.

Sherzer, Joel 1983. Kuna Ways of Speaking: An Ethnographic Perspective. Austin: University of Texas Press.

Sherzer, Joel; Wicks, Ann Sammie 1982. The Intersection of Music and Language in Kuna Discourse. In: Revista de Música Latinoamericana 3(2), 147-164. https://doi.org/10.2307/780134

Skilton, Amalia 2017. Esoteric morphology: vocable affixes in Máíhł̃ki shamanic song. In: Memorias del Congreso de Idiomas Indígenas de Latinoamérica VII / Proceedings of the Conference on Indigenous Languages of Latin America VII, 29-31 October 2015. Organized by the Center for Indigenous Languages of Latin America (CILLA), Teresa Lozano Long Institute of Latin American Studies at the University of Texas at Austin. https://ailla.utexas.org/node/99

Tedlock, Dennis 1983. The Spoken Word and the Work of Interpretation. Philadelphia: University of Pennsylvania Press. https://doi.org/10.9783/9780812205305 
Tsur, Reuven 1998. Poetic Rhythm: Structure and Performance. An Empirical Study in Cognitive Poetics. Berne: Peter Lang.

Turner, Frederick; Pöppel, Ernst 1988. Metered Poetry, the Brain, and Time. In: Rentschler, Ingo; Herzberger, Barbara; Epstein, David (eds.), Beauty and the Brain: Biological Aspects of Aesthetics. Basel, Boston, Berlin: Birkhäuser, 71-90. https://doi.org/10.1007/978-3-0348-6350-6_4

Urban, Greg 1986. Ceremonial Dialogues in Native South America. In: American Anthropologist 88(2), 371-386. https://doi.org/10.1525/aa.1986.88.2.02a00050

Urban, Greg 1988. Ritual Wailing in Amerindian Brazil. In: American Anthropologist 90(2), 385-400. https://doi.org/10.1525/aa.1988.90.2.02a00090

Zariquiey, Roberto 2011a. A Grammar of Kashibo-Kakataibo (Issue Abril). PhD Thesis. La Trobe University.

Zariquiey Biondi, Roberto 2011b. Aproximación dialectológica a la lengua cashibocacataibo (pano). In: Lexis 35(1), 5-46.

https://revistas.pucp.edu.pe/index.php/lexis/article/view/1257/1215

Zariquiey Biondi, Roberto 2013. Del < Kaschibo $>$ de Tessmann al cashibo-cacataibo contemporáneo: Algunas notas para la comprensión de la historia lingüística de un pueblo pano. In: Revista Brasileria de Linguística Antropológica 5(1), 159-192. https://doi.org/10.26512/rbla.v5i1.16546

Zariquiey Biondi, Roberto 2014. Canciones tradicionales (kakataibo). In: Archivo Digital de Lenguas Peruanas. http://repositorio.pucp.edu.pe/index/handle/123456789/35164

Zariquiey Biondi, Roberto 2018. A Grammar of Kakataibo. (Mouton Grammar Library 75). Berlin: De Gruyter Mouton. 